\title{
Implementation of the Internal Quality Assurance Process: Quality Mapping Analysis at State Senior High School in Tomohon City, North Sulawesi, Indonesia
}

\author{
Deisy Sampul'1, Benny B. Binilang'2 ${ }^{2}$ J.F. Senduk ${ }^{3}$, F.J.A Oentoe \\ ${ }^{1}$ Lembaga Penjaminan Mutu Pendidikan, Manado, Indonesia \\ 2,3,4 Universitas Negeri Manado, Manado, Indonesia
}

\begin{tabular}{|c|c|}
\hline (A) Check for updates open 0 access cc) (i) (2) & DOI : https://doi.org/10.46245/ijorer.v1i2.43 \\
\hline Article Info & ABSTRACT \\
\hline Article history: & The Internal Quality Assurance System (IQAS) has an important position \\
\hline Submitted: June 19, 2020 & in ensuring the quality of education of each education unit. A good internal \\
\hline Final Revised: July 09, 2020 & quality assurance process will guarantee the quality of education is \\
\hline Accepted: July 11, 2020 & maintained and will make it easier for schools to conduct quality mapping, \\
\hline Published Online: July 31, 2020 & preparing quality plans, fulfilling quality, evaluating, and determining \\
\hline Keywords: & quality standards. The purpose of this study is to describe the \\
\hline Achievement & implementation of internal quality assurance processes at state senior high \\
\hline Management & school in the City of Tomohon, North Sulawesi based on the quality report. \\
\hline Quality Assurance & This research was designed using qualitative descriptive research with the \\
\hline Quality Culture & data collection techniques include observation and documentation as well \\
\hline Quality Report & as data sourced from the Quality Report online application. The results of \\
\hline 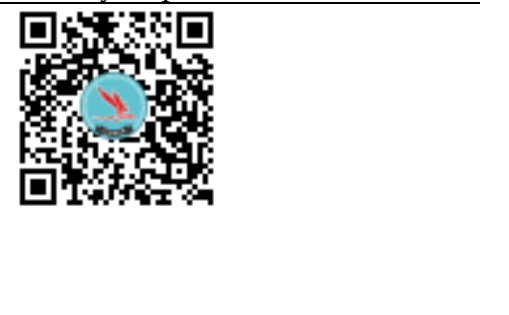 & $\begin{array}{l}\text { this study indicate that the internal quality assurance process at state senior } \\
\text { high school in Tomohon City has been carried out following national } \\
\text { education standards. The educational quality achievement still needs to be } \\
\text { improved so that there is consistency in fulfilling quality. Besides, a culture } \\
\text { of quality and cooperation must be fostered to support the internal quality } \\
\text { assurance process. Likewise in the internal quality assurance process that } \\
\text { requires support from various elements in the school, government, and } \\
\text { community environment. }\end{array}$ \\
\hline
\end{tabular}

\section{INTRODUCTION}

The issue of the quality of education is crucial because the quality of education is very influential in the progress of the nation (Akib et al., 2020). Education quality assurance is not only a matter of improvement at the classroom or school level but rather to meet stakeholder satisfaction and ensure accountability of the educational process to the community. The implementation of education quality assurance is the responsibility of each component in the education unit. The implementation of Education Quality Assurance in schools will ensure that school management, learning processes, and other programs are carried out to certain quality standards. In Indonesia, education quality standards have been set by the National Education Standards Agency (BSNP), as a quality reference for every educational institution. This quality reference covers eight national education standards that can guarantee the quality of education in Indonesia.

Quality education process if all components of education are involved in the education process itself. Whereas quality education in terms of educational outcomes refers to the level of success achieved by schools at any given time in various fields such as academics, skills, and the atmosphere and condition of the school (Ismail, 2008). Therefore, the relationship between all components of education needs to be optimized to support the quality of education. So important is the quality of education that various 
studies and studies have discussed at various levels such as development of educational quality management models (Herawan et al., 2014), quality improvement strategy (Suti, 2011), School-based management for improving the quality of education Aziz (2015), Nurokhim (2017) and education quality management research with a variety of focus (Fadhli, 2017; Darmarstuti \& Karwanto, 2014; Lolowang, 2008; Pamungkur, 2011). There is also a focus on the role of the principal in quality management (Liswiana et al., 2018; Lestari et al., 2019).

Quality improvement in education units cannot run well without a quality culture in all components of the school. Therefore, schools must carry out internal quality assurance activities, because this is the responsibility of the school to improve the quality of education and so that all educational processes carried out can be controlled for its quality (Aithal, 2015). This opinion states that the internal quality assurance system is a self-regulated responsibility of educational institutions aimed at continuous quality improvement and achieving academic excellence. Therefore, there is no other choice for schools except to continue to assess the quality of education in each school. Without the goodwill of every element in the school, the quality of education cannot be guaranteed. Besides that, several factors that can support efforts to improve quality are information management, analysis, and strategic planning (Diana, 2017).

The Internal Quality Assurance System (IQAS) is part of an education quality management system in Indonesia. In managing education quality assurance, the education quality management system can be interpreted as a management system to direct and control the education unit by establishing quality policies, targets, plans, and processes or procedures and achieving them continuously (continuous improvement). The expected target for quality management in education is to improve service quality, improve productivity and efficiency through improving performance and improving the quality of the education process so that it can produce graduates who satisfy or meet the needs of stakeholders (Sani et al., 2015).

Improving the quality of education is a top priority in all educational institutions (Umar \& Ismail, 2018). Quality assurance as an effort to analyze the process of education in schools has been regulated in the legislation in force in Indonesia. However, if there is no strong desire to improve the quality of education, national education standards will not be achieved. Therefore, efforts are needed to foster a culture of quality in every educational institution to carry out the quality assurance process, quality culture should be developed in each education unit. Quality culture must also grow in each of these components. Because the quality culture variable has a positive and significant effect on the implementation of a quality management system, which means increasing beliefs and behaviors that pay attention to quality, will further increase efforts to implement a quality management system (Muafi \& Nilmawati, 2015).

Concerning the education quality assurance study at the secondary education level, the government has established a quality assurance system for primary and secondary education. Quality assurance of primary and secondary education itself is a systematic, integrated, and sustainable mechanism to ensure that the entire process of providing education is following quality standards and regulations. In other words, the quality assurance process can guarantee the implementation of education is following the standards.

At the level of senior high school, quality assurance of education becomes very urgent because at this level students begin the learning stages that will prepare well for their academic future, namely the continuation of education at the next level. Thus, the 
quality of primary and secondary education needs to get serious attention. Especially when faced with the times, technological advances, and various future challenges that we have not yet been able to predict, such as the spread of the COVID-19 outbreak that has changed the process of education in Indonesia.

Based on preliminary observations at state senior high school in the City of Tomohon, there is a tendency for low-quality culture. This has an impact on the process of improving the quality of education in each school. Based on these considerations, this study seeks to describe the implementation process of internal quality assurance in the City of Tomohon, North Sulawesi. This study aims to describe the process of internal quality assurance in-state senior high school in Tomohon City, North Sulawesi. This study is important as a projection and prediction in the future quality assurance of education so that educational institutions in Tomohon are prepared with a variety of possibilities that can occur.

\section{RESEARCH METHOD}

This research was designed using quantitative descriptive research. This research is more focused on the process of internal quality assurance, focusing on meaning and experience and interacting physically with people in school as locations in this research, and institutions to observe the process and phenomena. This research is located in Tomohon city, North Sulawesi, Indonesia. Quality Reports based in the Online Application Quality Reporting, Quality Assurance of Primary and Secondary Education, Indonesia Ministry of Education and Culture. Besides, this study also makes the quality assurance process carried out by the school principal and the quality assurance team as a source of data. This study places the researcher as the main instrument of sampling from the data source which was done purposively and snowball (Sugiyono, 2017). Data collection was conducted by observation, documentation techniques, and quality reports cards. Researchers conducted data analysis with content analysis techniques and then using an analysis model consisting of data collection, data reduction and presentation of conclusions (Miles \& Huberman, 1992). Based on this process, researchers obtain the data and information needed in this study, so that this study gets results according to the research objectives.

\section{RESULTS}

The internal quality assurance process carried out refers to the National Education Standards established by the National Education Standards Agency namely Graduates Competency Standards, Content Standards, Process Standards, Education Assessment Standards, Educators and Education Personnel Standards, Facilities and Infrastructure Standards, Management Standards, and Financing Standards (Kementerian Pendidikan dan Kebudayaan, 2017). This standard is used by all educational institutions in Indonesia as a quality reference.

The quality of education can be seen in two ways, namely referring to the educational process and educational outcomes (Suryosubroto, 2004). The assessment of the internal quality assurance process is carried out following guidelines from the ministry of education and culture. The ministry of education and culture has provided a quality report application that can be filled out by each education unit according to the conditions in the school. The quality of the school was measured in five categories with predetermined upper and lower limits. The educational quality achievements in Primary and Secondary Education are categorized as follows: 
Table 1. Quality achievement category.

\begin{tabular}{lccc}
\hline & Category & Upper Limit & Lower Limit \\
\hline$\star$ & Heading to SNP 1 & 0 & 2.04 \\
\hline$\star \star$ & Heading to SNP 2 & 2.05 & 3.70 \\
$\star \star \star$ & Heading to SNP 3 & 3.71 & 5.06 \\
\hline$\star \star \star \star$ & Heading to SNP 4 & 5.07 & 6.66 \\
\hline$\star \star \star \star \star$ & SNP & 6.67 & 7 \\
\hline
\end{tabular}

Based on the results of the study, obtained data about the achievement of the quality of education in high schools in the city of Tomohon, especially at State Senior High School 1 Tomohon and State Senior High School 2 Tomohon as research locations are as follows:

\section{State Senior High School 1 Tomohon Quality Achievement}

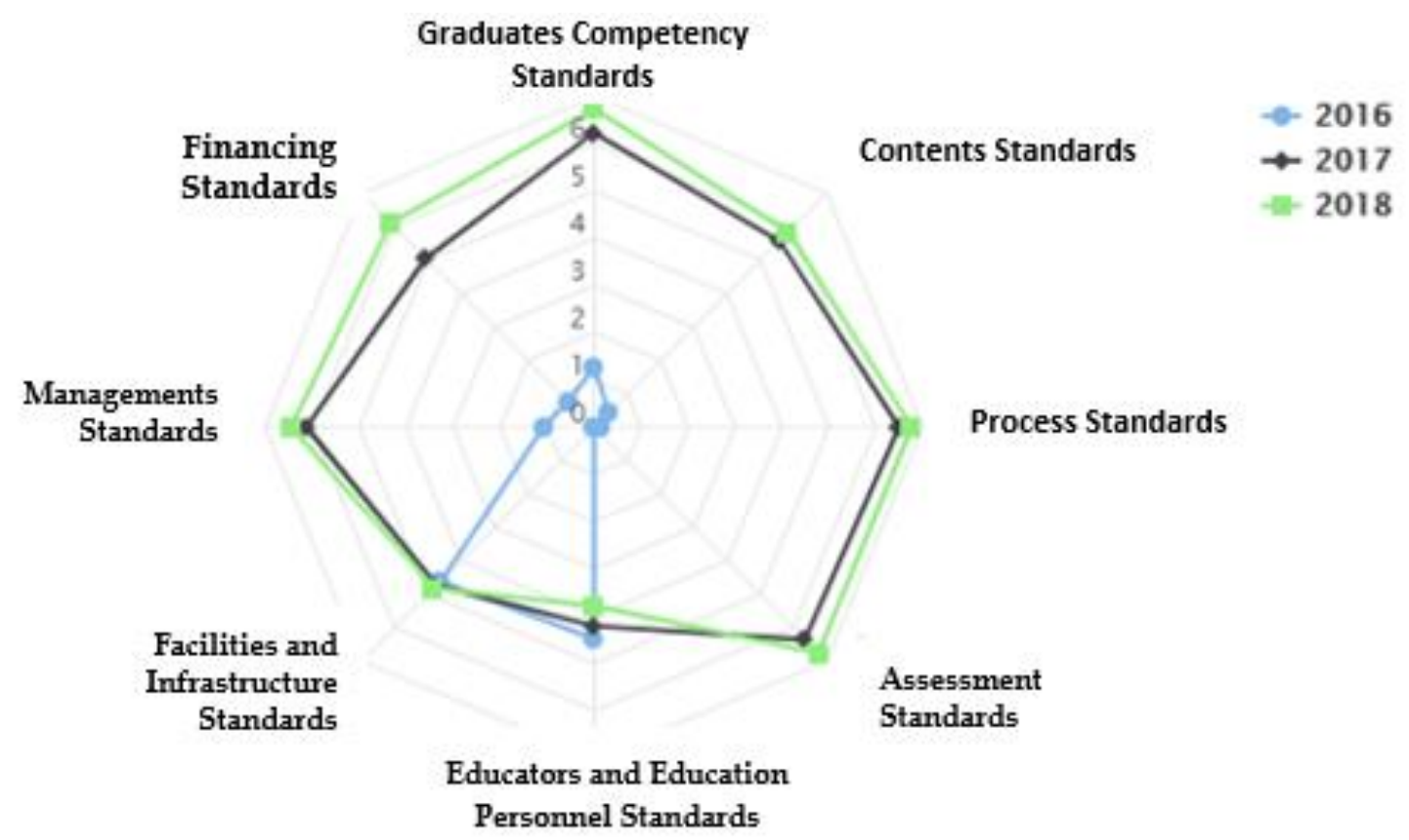

Figure 1. Quality achievement at State Senior High School 1 Tomohon.

In Figure 1, educational quality achievements in State Senior High School 1 Tomohon continue to increase from year to year. Recorded in 2016 to 2018 an increase in the quality of education scores. The quality of educational attainment at State Senior High School 1 Tomohon in 2018 as the latest report shows a high score on the standard process and assessment, while the lowest on the standard of educators and education personnel, for more details, the educational quality achievement score at Tomohon High School can be described in the following Table 2. 
Table 2. State Senior High School 1 Tomohon quality achievement score (latest report).

\begin{tabular}{lc}
\hline Quality Standards & School Achievements \\
\hline Graduates Competency Standards & 6.74 \\
Contents Standards & 5.84 \\
Process Standards & 6.76 \\
Assessment standards & 6.76 \\
Educators and Education Personnel Standards & 3.78 \\
Facilities and & 4.82 \\
Infrastructure Standards & \\
Management Standards & 6.45 \\
Financing Standards & 6.12 \\
\hline
\end{tabular}

Table 2 shows the achievements of State Senior High School 1 Tomohon on each standard. Following Figure 1, the achievement of the process standard and the education evaluation standard is the highest (6.76). Then the graduate competency standard (6.74). While the lowest is the standard achievement of educators and education personnel (3.78).

\section{State Senior High School 2 Tomohon Quality Achievement}

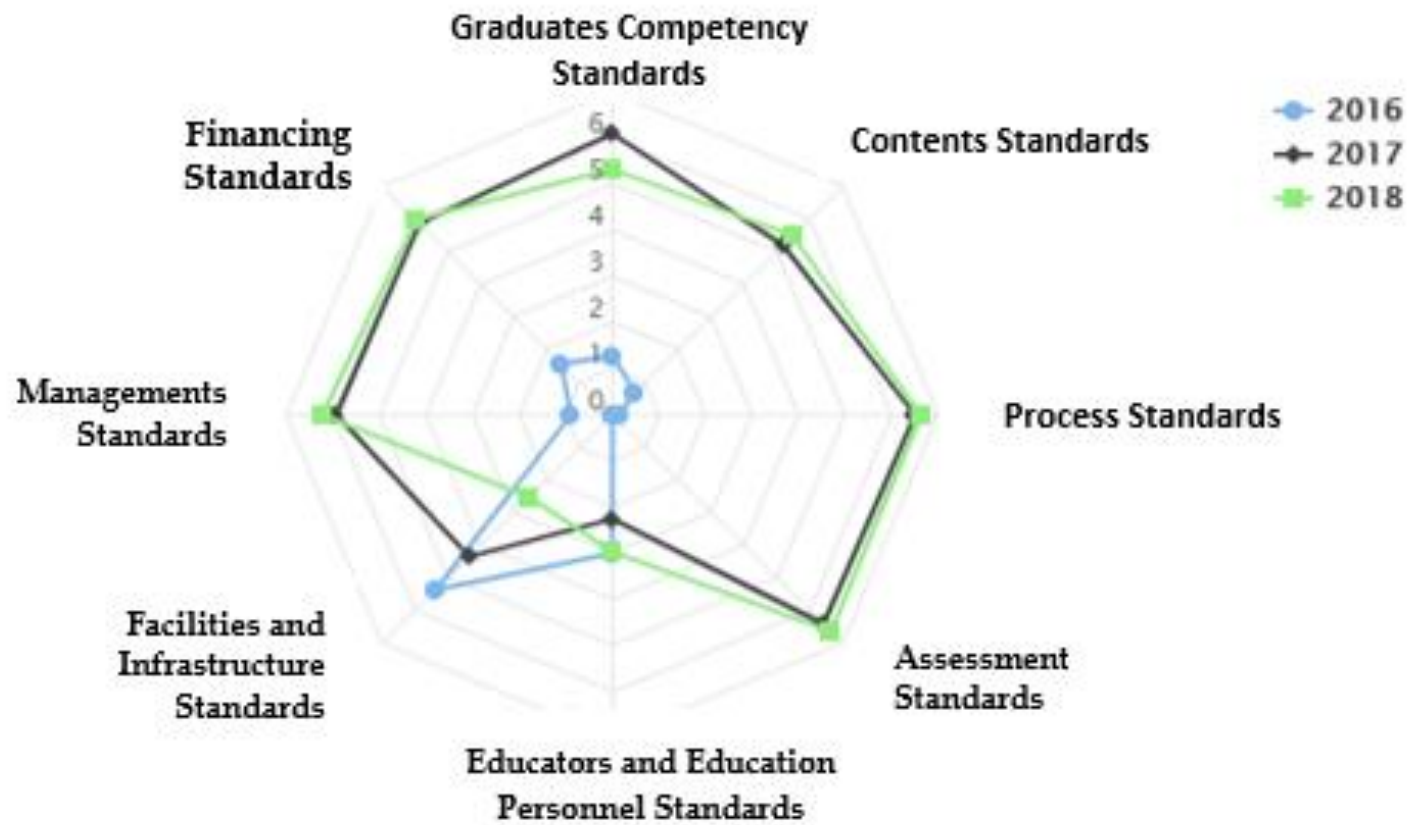

Figure 2. Quality achievement at State Senior High School 2 Tomohon.

Figure 2 shows that the results of the quality of education at State Senior High School 2 Tomohon vary from year to year. There is an increase but there is also a decrease from the previous year. Graduates' competency standards and educational facilities and infrastructure standards have decreased from the previous year. This reduction is a record of improvement for inclusion in the quality improvement program the following year. However, there is a slight increase in the score of quality achievement in some standards. More clearly the results of the achievement of the quality of education at State Senior High School 2 Tomohon can be described as follows in Table 3.

Table 3. State Senior High School 2 Tomohon quality achievement score (latest report). 


\begin{tabular}{lc}
\hline Quality Standards & School Achievements \\
\hline Graduates Competency Standards & 5.32 \\
Contents Standards & 5.48 \\
Process Standards & 6.63 \\
Assessment standards & 6.64 \\
Educators and Education Personnel Standards & 2.97 \\
Facilities and & 2.53 \\
Infrastructure Standards & \\
Management Standards & 6.23 \\
Financing Standards & 5.98
\end{tabular}

Table 3 shows the quality achievements of State Senior High School 2 Tomohon in the standard process (6.63) and the highest educational assessment standard (6.64) being the highest. While the lowest is the achievement of educational facilities and infrastructure standards (2.53). This score is quite low if it refers to the level of the category of educational quality achievement.

\section{DISCUSSION}

Based on the findings of the above research, it can be stated that the internal quality assurance in the city of Tomohon especially at State Senior High School 1 Tomohon and State Senior High School 2 Tomohon has been carried out following the education quality reference of the National Education Standards Board (BSNP). Internal quality assurance by this education unit can be used to make improvements and improve the quality of education in the following years because in the education quality assurance system implemented in primary and secondary education, it is directed that every education unit in implementing all educational processes according to policies, targets, plans, and procedures, as well as continuous quality improvement. Based on the Regulation of the Minister of National Education Number 63 Year 2009 regarding the Education Quality Assurance and Improvement System, it is stated that the quality of education is the level of intelligence of the nation's life that can be achieved from the application of the National Education System.

The achievement of the education quality score at State Senior High School 1 Tomohon shows continuous improvement from year to year, this is consistent with the results of observations at the location where all elements of the school strive to support education quality improvement programs designed by the school. Whereas at State Senior High School 2 Tomohon, although the school has tried to meet the quality of education according to national standards, it still needs to be improved on several standards such as educational facilities and infrastructure standards. This is where the importance of the integrity of an education quality assurance system. Relationships and cooperation with local and central government also determine the achievement of education quality. Cooperation and unity of the education quality assurance system is very important to carry out the quality assurance process. Therefore, education quality assurance is carried out systemically and integrated by education units or programs, organizers of educational units or programs, District/City Governments, Provincial Governments and Central Governments and the public. Therefore, quality assurance is a system of quality management.

The unity of this system has a relationship that is related to one another to ensure that all educational quality assurance processes run optimally. This is one part of the organization's management system in the quality management system. Gaspersz's 
study mentions five main sections that describe an organization's management system, including a. Quality Management System (QMS), b. management responsibility, c. resource management, $d$. product realization and e. analysis, measurement, and improvement (Gasperz, 2001). Whereas in the ISO 9000 management series explains that there are eight quality management principles namely: (a) customer focus, (b) leadership, (c) involvement of people, (d) process approach, (e) approach systems for management, (f) continuous improvement, (g) factual approaches to decision making, and (h) mutually beneficial relationships with suppliers (Maulana, 2011).

The above description provides an understanding that quality assurance needs to be managed properly in a quality management system. A system will run optimally if all the components in the system can perform tasks and functions properly. Likewise, in the quality assurance process, education units, planners, policymakers, and other resources, must work together positively in creating a better quality of education. According to the explanation, the whole process of quality assurance is aimed at producing better and higher quality education. Education quality assurance becomes an important factor in achieving better education quality (Sulistyowati et al., 2017). This indicates that quality assurance requires process and corrective steps. School quality assurance needs to establish quality accomplishment which has been established by arranging the steps of the implementation of the quality assurance program (Sulistyowati et al., 2017). Quality assurance requires a program that is structured in a directed path from beginning to end according to established standards.

In the case faced by State Senior High School 2 Tomohon, which experienced a decrease in the achievement of quality standards of facilities and infrastructure, it is necessary to make improvements by planning a quality fulfillment program. Planning and fulfillment activities are carried out by involving all competent school elements so that improvements and improvements can be achieved. This is important so that schools can provide confidence to stakeholders regarding the quality of education. Because the quality assurance process provides benefits for education units in clarifying the vision and mission and goals of the school to stakeholders, can open opportunities for all parties to think of an appropriate system for schools, clarify the job description or division of tasks, and have goals or orientation clear about the standard to be achieved. So, quality standards are part of customer satisfaction (Wibowo \& Azimah, 2016). Besides, quality assurance becomes a control system to keep all processes running according to standards and becomes a correction if there are errors in the education process (Sani et al., 2015).

To carry out the quality assurance process, quality culture should be developed in each education unit. Quality culture must also grow in each of these components. Because the quality culture variable has a positive and significant effect on the implementation of a quality management system, which means increasing beliefs and behaviors that pay attention to quality, it will further increase efforts to implement a quality management system (Muafi \& Nilmawati, 2015). In connection with education quality assurance at the secondary education level, the government has established a quality assurance system for primary and secondary education. Quality assurance of primary and secondary education itself is a systematic, integrated, and sustainable mechanism to ensure that the entire process of providing education is following quality standards and regulations. In other words, the quality assurance process can guarantee the implementation of education is under the standards. At the level of senior high school, quality assurance of education becomes very urgent because at this level 
students begin the stages of learning that will prepare well for their academic future, namely the continuation of education at the next level. Thus, the quality of the senior high school level needs to get serious attention.

\section{CONCLUSIONS}

Based on the results of the study it can be concluded that the process of implementing internal quality assurance in Tomohon City High School has taken place in accordance with national education standards by referring to the references and quality indicators from the Directorate of Primary and Secondary Education, the Ministry of Education and Culture of the Republic of Indonesia. Analysis of educational quality achievements based on quality report cards shows that there is a need to improve the quality of education, especially in State Senior High School 1 and State Senior High School 2 Tomohon. Collaboration between school elements and collaboration with the government and related agencies is very important to ensure the quality assurance process can take place and can show continuous improvement. Therefore, it is recommended to foster a culture of quality and enhance cooperation in achieving the planned quality standards of education. Due to the limitations of this study, it can be recommended to further researchers to explore quality culture in each education unit as an important part in improving the quality of education.

\section{ACKNOWLEDGEMENTS}

Acknowledgments the researchers conveyed to the Principal of State Senior High School 1 Tomohon and the Principal of State Senior High School 2 Tomohon and the school quality assurance team. Besides, appreciation and thanks to the Education Quality Assurance Team (LPMP) North Sulawesi for permission to access school quality report that strongly support this research. We also thank the editor of IJORER and all the reviewers who received and provided input for this article.

\section{REFERENCES}

Aithal, P. S. (2015). Internal quality assurance cell and its contribution to quality improvement in higher education institutions: A case of SIMS. GE-International Journal of Management Research, 3(5), 70-83.

Akib, E., Imran, M. E., Mahtari, S., Mahmud, M. R., Prawiyogy, A. G., Supriatna, I., \& Ikhsan, M. H. (2020). Study on implementation of integrated curriculum in Indonesia. IJORER : International Journal of Recent Educational Research, 1(1), 39-57.

Aziz, A. Z. (2015). Manajemen Berbasis sekolah: Alternatif peningkatan mutu pendidikan madrasah. El-Tarbawi, VIII(1), 69-92.

Darmarstuti, H., \& Karwanto. (2014). Manajemen sarana dan prasarana dalam upaya peningkatan kualitas pembelajaran pada jurusan teknik komputer dan informatika di SMK Negeri 2 Surabaya. Jurnal Inspirasi Manajemen Pendidikan, 3(3), 9-20.

Diana, N. (2017). Evaluasi manajemen mutu internal di fakultas tarbiyah dan keguruan dengan metode malcolm baldrige criteria for education. Tadris: Jurnal Keguruan dan Ilmu Tarbiyah, 2(2), 111-120.

Herawan, E., \& Kurniady, D.A. \& Sururi. (2014). Pengembangan Model Manajemen Mutu Pendidikan pada SMK di Kota Bandung. Jurnal Penelitian Pendidikan LPPM UPI, 14(2), 199-208.

Fadhli, M. (2017). Manajemen peningkatan mutu pendidikan. Tadbir: Jurnal Studi 
Manajemen Pendidikan, 1(2), 215-240.

Gasperz, V. (2001). ISO 9001:2000 and continual quality improvement. Jakarta: Gramedia Pustaka Utama.

Ismail, F. (2008). Manajemen berbasis sekolah: Solusi peningkatan kualitas pendidikan. Jurnal Pendidikan Islam Iqra', 2(2), 1-17.

Kementerian Pendidikandan Kebudayaan. (2017). Indikator mutu dalam penjaminan mutu pendidikan dasar dan menengah. Jakarta: Direktorat Pendidikan Dasar dan Menengah.

Lestari, D., Abdullah, G., \& Murniati, N. A. N. (2019). Peran Manajerial kepala sekolah dalam peningkatan mutu SDN Mukiran 04 kecamatan Kaliwungu kabupaten Semarang. Jurnal Manajemen Pendidikan (JMP), 8(2), 225-241.

Liswiana, D., Nurkolis, N., \& Abdullah, G. (2018). Peran kepala sekolah dalam meningkatkan mutu SD Islam Al Azhar 25 Semarang. Jurnal Manajemen Pendidikan (JMP), 7(3), 328-344.

Lolowang, R.M. (2008). Implementasi Manajemen peningkatan mutu berbasis sekolah di sekolah dasar. Jurnal Ilmu Pendidikan, 15(2), 102-110.

Maulana, A. (2011). Analisis Penerapan sistem manajemen mutu ISO 9001:2008 pada kantor manajemen mutu Institut Pertanian Bogor. Bogor: Institut Pertanian Bogor.

Miles, M.B., \& Huberman, A. M.. (1992). An expanded sourcebook qualitative data analysis. California: Sage Publication.

Muafi, M., \& Nilmawati, N. (2015). Budaya mutu dan implementasi ISO 2008: 9001 serta Dampaknya terhadap komitmen organisasional. Jurnal Dinamika Manajemen, 5(1), 33-47.

Nurokhim, N. (2017). Manajemen berbasis sekolah: Solusi Peningkatan mutu pendidikan madrasah. Jurnal Kependidikan, 5(2), 247-260.

Pamungkur. (2011). Membangun strategi manajemen peningkatan mutu pendidikan pendidikan melalui implementasi total quality management (TQM). Jurnal Penjaminan Mutu, 1-20.

Sani, R. A., Pramuniati, I., \& Mucktiany, A. (2015). Penjaminan mutu sekolah. Jakarta: PT. Bumi Aksara.

Sugiyono. (2017). Download Metode Penelitian Kuantitatif Kualitatif dan R \& D. Bandung: Alfabeta.

Sulistyowati, R. A., Supriyanto, A., \& Mustiningsih, M. (2017). Management of internal quality assurance in character education. Jurnal Pendidikan Humaniora, 5(1), 70-75.

Suryosubroto, B. (2004). Manajemen pendidikan di sekolah. Jakarta: PT. Rineka Cipta.

Suti, M. (2011). Strategi peningkatan mutu di era otonomi pendidikan. Jurnal MEDTEK, $3(2), 1-6$.

Umar, M., \& Ismail, F. (2018). Peningkatan mutu lembaga pendidikan ISLAM (Tinjauan konsep mutu Edward Deming dan Joseph Juran). Jurnal Ilmiah Iqra', 11(2), 1-24.

Wibowo, A., \& Azimah, A. (2016). Rancang bangun sistem informasi penjaminan mutu perguruan tinggi menggunakan metode throwaway prototyping development. Seminar Nasional Teknologi Informasi dan Multimedia, 4(1), 103-107. 


\section{*Deisy Sampul (Corresponding Author)}

Lembaga Penjaminan Mutu Pendidikan (LPMP) Sulawesi Utara

Jl. Raya Manado Tomohon, Pineleng II, Kec. Pineleng, Kabupaten Minahasa, Sulawesi Utara, Indonesia

Email: deisysampul2020@gmail.com

\section{Benny B. Binilang}

Program Pascasarjana Universitas Negeri Manado, Indonesia.

Jl. Matani Satu, Tomohon Tengah, Kota Tomohon, Sulawesi Utara Kota Tomohon 95618, Indonesia.

\section{J.F. Senduk}

Program Pascasarjana Universitas Negeri Manado, Indonesia.

Jl. Matani Satu, Tomohon Tengah, Kota Tomohon, Sulawesi Utara Kota Tomohon 95618, Indonesia.

\section{F.J.A. Oentoe}

Program Pascasarjana Universitas Negeri Manado, Indonesia.

J1. Matani Satu, Tomohon Tengah, Kota Tomohon, Sulawesi Utara Kota Tomohon 95618, Indonesia. 